\title{
Truncation Points for Selection in a Population with Overlapping Generations
}

\author{
Hiroshi Shimizu and Abdul Ghaffar \\ Department of Animal Science, Faculty of Agriculture, \\ Hokkaido University, Kita-ku, Sapporo-shi 060
}

(Received April 20, 1992)

\begin{abstract}
Simple procedures for computing the truncation points of selection such as (1) predicted genetic values on truncation points and (2) average genetic values of selected parents should be on the same level for each age class of parents in a population with overlapping generations, are presented. To illustrate these procedures, the path of bulls' dams in a dairy cattle population was taken as a choice for a numerical example. The results were compared with two other selection methods, intra-age selection and selection on common truncation point on phenotypic values to assess their practicability in optimizing the age structure and prediction of genetic response to truncation selection. The problems in pursuing such selection policies are also discussed.
\end{abstract}

Anim. Sci. Technol. (Jpn.) 63 (11) : 1109-1114, 1992

Key words : truncation points, selection across age classes, age structure

In a livestock population with overlapping generations, the optimum breeding policy is based on the best combination of selected proportions within and across age classes. Inter-age class selection affects the age structure of parents which determines the generation interval and reflects on the rate of genetic improvement. HILL ${ }^{8,9)}$ developed a formal matrix method to predict and compare the genetic responses to selection for the short and long term improvement breeding plans with fixed age structure of parents in a population with overlapping generations and sub-groups. HopKINS and JAMES ${ }^{10,11)}$ demonstrated the recurrence relationship to relate the breeding values of age-sex classes from different time periods which imply the effect of age structure and initial genetic differences between age groups. It has been pointed out that the methods are not suitable for predicting the response to selection with optimal generation intervals ${ }^{13\rangle}$, since the generation interval is a fixed input parameter of these models. The optimum age structure is required to construct an optimum breeding plan. BICHARD et al. ${ }^{1)}$ considered the fact that when genetic gains are being made in a population where generations overlap, progeny of younger parents will, on average, be genetically superior to progeny of older parents. Further, the rate of gain can be increased by making allowances for the genetic effects of parental age. They concluded this while comparing the following three selection criteria : 1) selection on the deviation from the means of each parental age class, 2) at common truncation point on phenotypic values, and 3 ) at the truncation point on the same predicted breeding value. They found the truncation point by trial and error using the Table of probits proposed by Fisher and YATES ${ }^{6)}$. However, they did not present the systematic methodology which could be combined in a computing program. DUCrocQ and QUAAs ${ }^{5)}$ presented an algorithm for determining the 
truncation point following the optimal rule proposed by BICHARD et al. ${ }^{1)}$ using Newton's $\operatorname{method}^{4)}$. This algorithm coincides with the second method of BICHARD et al. ${ }^{11}$.

The main objective of this study, is to extend their algorithm to calculate the truncation point of selection for the third method and a 'new' truncation point which takes account the distribution of selected parents from different age classes, at the same average genetic merits. The procedures are also applied to decide an optimal proportion of parents selected across age subgroups or introduced from an exotic population.

\section{Materials and Methods}

Methods of selection: Four methods of selection differentiated by the truncation point of selection among age classes were settled, including the three methods of BICHARD et $a l^{13}$, as :

(1) selection of fixed proportion within age classes : Method I,

(2) selection at the common truncation point on phenotypic value or selection index predictor of breeding value: Method II,

(3) selection at each truncation point on the same predicted genetic value: Method III, and

(4) selection at each truncation point with the same average genetic values of selected parents : Method IV.

General formulae: Average genetic merit of the selected parents over the candidates for selection is expressed as :

$$
\mathrm{g}=\operatorname{Ir} \sigma_{\mathrm{A}}
$$

where $r$ refers to accuracy of selection, $\sigma_{\mathrm{A}}$ to genetic standard deviation and I to selection intensity. Under the assumption of normal distribution $\left(\mathrm{N}\left(0, \sigma^{2}\right)\right)$

$$
\mathrm{I}=\mathrm{f}(\mathrm{k}) / \mathrm{F}(\mathrm{k})
$$

where,

$\mathrm{f}(\mathrm{k})$ refers to the density at $\mathrm{k}$ in a normal distribution :

$$
\mathrm{f}(\mathrm{k})=\exp \left[-\mathrm{k}^{2} /\left(2 \sigma^{2}\right)\right] /(\sqrt{2 \pi} \sigma)
$$

$$
F(k)=\int_{k}^{\infty} f(x) d x
$$

Calculation of truncation point for selection: If a genetic trend exists in the population with overlapping generations and the accuracy of selection increases as candidate gets older, animals of different age classes come from the distribution with different means and variances. It assumed that all animals are kept from one year to another except for accidental reasons. Selection is usually performed by truncation within or across age classes. Truncation points may be unique over all age classes or different among age classes, depending upon the selection objectives. The unit of measurements, the genetic standard deviation, was assumed to be constant over all age classes. Additive genetic values and its selection index predictor are normally distributed with $N\left(m_{i}, 1\right)$ and $N\left(m_{i}, 1 / r_{i}{ }^{2}\right)$ for the $i-t h$ age class respectively, where $m_{i}$ refers to the average genetic values of the $i$-th age before selection and $r_{i}$ to the accuracy of selection.

Method I : For Method I, the proportions of selected parents among age classes were identical to the distribution of candidates and the selection intensity may be computed according to Burrows ${ }^{2)}$.

Method II : When parents are selected at the common truncation point $K$, the overall selected proportion $(\mathrm{P})$ is

$$
P=\sum q_{i} F\left[\left(K-m_{i}\right) r_{i}\right]
$$

DUCROCQ and QUAAs ${ }^{4)}$ solved this nonlinear equation iteratively for $K$ using Newton's method $^{4)}$ as described below. The deviation of calculated proportion from a given proportion $\left(\mathrm{P}^{*}\right)$ is

$$
d(K)=P-P^{*}
$$

To get $K$ such that $d(K)=0$, start with some prior value $\mathrm{K}_{0}, e . g . \mathrm{K}_{0}=$ means of the youngest age class, and iterate on :

$$
K_{n+1}=K_{n}-d\left(K_{n}\right) / d^{\prime}\left(K_{n}\right)
$$

where

$$
\mathrm{d}^{\prime}\left(\mathrm{K}_{\mathrm{n}}\right)=-\Sigma \mathrm{q}_{\mathrm{i}} \mathrm{r}_{\mathrm{i}} \mathrm{f}\left[\left(\mathrm{K}_{\mathrm{n}}-\mathrm{m}_{\mathrm{i}}\right) \mathrm{r}_{\mathrm{i}}\right]
$$

Once $\mathrm{K}$ is obtained, other relevant quantities 


\section{Truncation Points of Selection}

are calculated. The proportion of the parents selected from the $i$-th age class $\left(p_{i}\right)$ to total number of selected parents is

$$
\mathrm{p}_{\mathrm{i}}=\left(\mathrm{q}_{\mathrm{i}} / \mathrm{P}^{*}\right) \mathrm{F}\left[\left(\mathrm{K}-\mathrm{m}_{\mathrm{i}}\right) \mathrm{r}_{\mathrm{i}}\right]
$$

Average genetic superiority of the parents $(\Delta \mathrm{g})$ selected across age classes as the deviation from the mean of the youngest age $\left(\mathrm{m}_{\mathrm{c}}\right.$ : subscript $c$ refer to the youngest age class) is

$$
\begin{aligned}
\Delta \mathrm{g}= & \sum \mathrm{p}_{\mathrm{i}}\left\{\mathrm{r}_{\mathrm{i}} \mathrm{f}\left[\left(\mathrm{K}-\mathrm{m}_{\mathrm{i}}\right) \mathrm{r}_{\mathrm{i}}\right] /\right. \\
& \left.\mathrm{F}\left[\left(\mathrm{K}-\mathrm{m}_{\mathrm{i}}\right) \mathrm{r}_{\mathrm{i}}\right]+\mathrm{m}_{\mathrm{i}}-\mathrm{m}_{\mathrm{c}}\right\}
\end{aligned}
$$

In this case, truncation point is common to all age classes.

Method III: Assuming the highest genetic means for the youngest age class and the truncation point for this class as $K_{c}$ (Fig. 1), then, the genetic values of animals at $K_{c}$ in the $i$-th age class are $m_{i}+\left(K_{c}-m_{i}\right) r_{i}{ }^{2}$ and the truncation point $\left(\mathrm{K}_{\mathrm{i}}\right)$ where animals in the $\mathrm{i}$-th age class should have the same genetic values as animals at $K_{c}$ in the youngest age is

$$
\begin{aligned}
\mathrm{K}_{\mathrm{i}}= & {\left[\left(\mathrm{m}_{\mathrm{c}}-\mathrm{m}_{\mathrm{i}}\right)+\left(\mathrm{K}_{\mathrm{c}}-\mathrm{m}_{\mathrm{c}}\right) \mathrm{r}_{\mathrm{c}}{ }^{2}\right.} \\
& \left.+\mathrm{m}_{\mathrm{i}} \mathrm{r}_{\mathrm{i}}{ }^{2}\right] / \mathrm{r}_{\mathrm{i}}{ }^{2}
\end{aligned}
$$

When the accuracy of selection is same among age classes $\left(r_{c}=r_{i}\right)$, marginal deviation $\left(K_{-}\right.$ $K_{c}$ ) at the same predicted genetic values is

$$
\mathrm{K}_{\mathrm{c}}-\mathrm{K}_{\mathrm{i}}=\left(\mathrm{m}_{\mathrm{i}}-\mathrm{m}_{\mathrm{c}}\right)\left(1-\mathrm{r}_{\mathrm{c}}{ }^{2}\right) / \mathrm{r}_{\mathrm{c}}{ }^{2}
$$

which coincided with equation (2) of BICHARD et $a l .{ }^{1)}$. The equations (5) to (10) are modified by transferring $\mathrm{K}$ to the truncation point for each age class $\left(\mathrm{K}_{\mathrm{i}}\right)$ as :

$$
\begin{aligned}
& \mathrm{P}=\sum \mathrm{q}_{\mathrm{i}} \mathrm{F}\left[\left(\mathrm{K}_{\mathrm{i}}-\mathrm{m}_{\mathrm{i}}\right) \mathrm{r}_{\mathrm{i}}\right] \\
& \mathrm{h}(\mathrm{K})=\mathrm{P}-\mathrm{P}^{*} \\
& \mathrm{~K}_{\mathrm{c}, \mathrm{n}+1}=\mathrm{K}_{\mathrm{c}, \mathrm{n}}-\mathrm{h}\left(\mathrm{K}_{\mathrm{n}}\right) / \mathrm{h}^{\prime}\left(\mathrm{K}_{\mathrm{n}}\right) \\
& \mathrm{h}^{\prime}\left(\mathrm{K}_{\mathrm{n}}\right)=-\sum \mathrm{q}_{\mathrm{i}} \mathrm{r}_{\mathrm{i}} \mathrm{f}\left[\left(\mathrm{K}_{\mathrm{i}, \mathrm{n}}-\mathrm{m}_{\mathrm{i}}\right) \mathrm{r}_{\mathrm{i}}\right] \\
& \mathrm{p}_{\mathrm{i}}=\left(\mathrm{q}_{\mathrm{i}} / \mathrm{P}^{*}\right) \mathrm{F}\left[\left(\mathrm{K}_{\mathrm{i}}-\mathrm{m}_{\mathrm{i}}\right) \mathrm{r}_{\mathrm{i}}\right] \\
& \Delta \mathrm{g}=\sum \mathrm{p}_{\mathrm{i}}\left(\mathrm{r}_{\mathrm{i}} \mathrm{f}\left[\left(\mathrm{K}_{\mathrm{i}}-\mathrm{m}_{\mathrm{i}}\right) \mathrm{r}_{\mathrm{i}}\right] /\right. \\
& \left.\quad \mathrm{F}\left[\left(\mathrm{K}_{\mathrm{i}}-\mathrm{m}_{\mathrm{i}}\right) \mathrm{r}_{\mathrm{i}}\right]+\mathrm{m}_{\mathrm{i}}-\mathrm{m}_{\mathrm{c}}\right\}
\end{aligned}
$$

Combining the equation (11) with (6.1) to (8.1), $K_{c}$ can be computed such that $h(K)=0$, and thus $K_{\mathrm{i}}$ is calculated from equation (11).

Method IV: Again, when the truncation point of selection for the youngest age class is $K_{c}$, the selection intensity $\left(I_{c}\right)$ is calculated from equation (2). The standardized selection differentials (selection intensity $\left(\mathrm{I}_{\mathrm{i}}{ }^{*}\right)$ ), in which

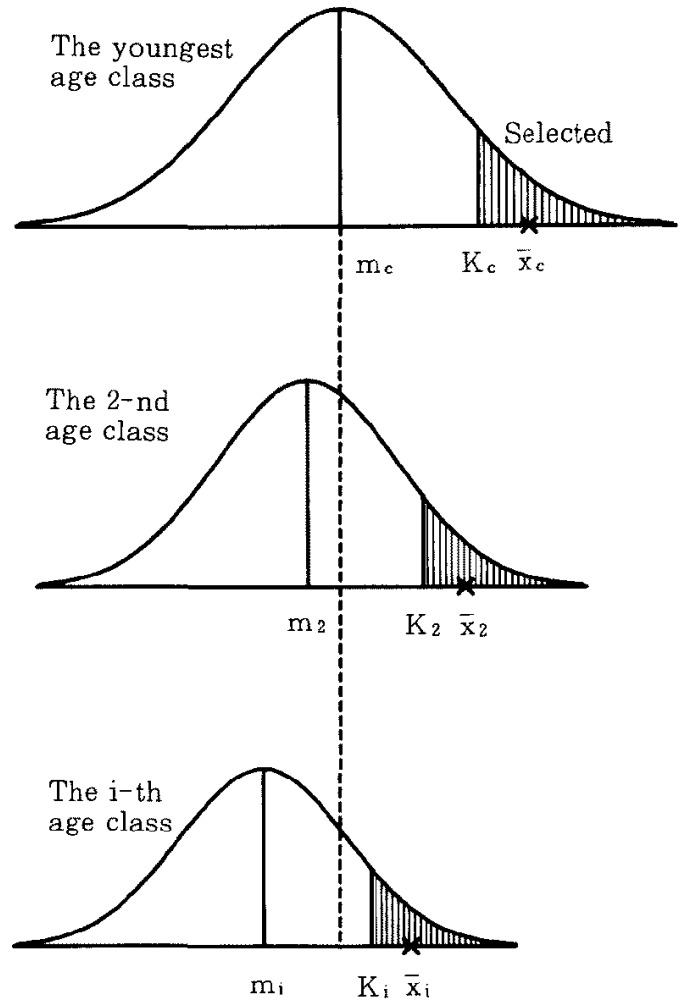

Fig. 1. Illustration of the symbols and distribution of different parental age classes with overlapping generations. $\mathrm{m}=$ genetic means, $\mathrm{K}=$ truncation point, $\overline{\mathrm{x}}=$ means of selected parent.

the average genetic values of selected parents in the i-th age class are on the matching level of the average in the youngest age class, are

$$
\mathrm{I}_{\mathrm{i}}^{*}=\left(\mathrm{m}_{\mathrm{c}}-\mathrm{m}_{\mathrm{i}}+\mathrm{r}_{\mathrm{c}} \mathrm{I}_{\mathrm{c}}\right) / \mathrm{r}_{\mathrm{i}}
$$

Truncation point $(\mathrm{K})$ with a given $\mathrm{I}^{*}$ can be computed using Newton's Method ${ }^{3)}$. From equation (2),

$$
\mathrm{I}=\mathrm{f}[(\mathrm{K}-\mathrm{m}) \mathrm{r}] / \mathrm{F}[(\mathrm{K}-\mathrm{m}) \mathrm{r}]
$$

The deviation of calculated $I$ from a given $I^{*}$ is,

$$
\begin{aligned}
& e(K)=I-I^{*} \\
& K_{n+1}=K_{n}-e\left(K_{n}\right) / e^{\prime}\left(K_{n}\right)
\end{aligned}
$$

where,

$$
e^{\prime}\left(K_{n}\right)=I_{n}\left[I_{n}-\left(K_{n}-m\right) r\right],
$$

$e^{\prime}\left(K_{n}\right)$ is the rate of change in $I$ at $K_{n}$. The $e^{\prime}$ $\left(K_{n}\right)$ can be obtained by differentiating the equation (13) with a given $K_{n}$. Thus, the 


\section{Shimizu and Ghaffar}

truncation point for each age class $\left(\mathrm{K}_{\mathrm{i}}\right)$ for a given $\mathrm{I}_{\mathrm{i}}{ }^{*}$ based on $\mathrm{K}_{\mathrm{c}}$ can be obtained such that $e(K)=0$. Combining the equations (12) to (16) with (6.1) to (8.1) and asymptotically approximating $\mathrm{K}_{\mathrm{c}}$ to the optimum value with the condition of equation (12), optimal truncation point for each age class can be obtained interatively.

Since the size of the actual animal population is not infinite, actual selection intensity (I) in equations (10) and (10.1) should be recalculated according to BuRRows ${ }^{2}$.

\section{Results and Discussion}

Since the path of bull's dams has many age classes, and older cows have a higher accuracy of selection, the algorithms proposed were applied to this path to illustrate the merit of its application. Main parameters used are listed in the upper 4 lines of Table 1. A unique trait of interest for selection was assumed to be milk production. The genetic differences

Table 1. Comparison of different selection criteria on age structure, truncation point of selection and genetic superiorities.

\begin{tabular}{|c|c|c|c|c|c|c|c|}
\hline & & \multicolumn{6}{|c|}{ Age classes (years) } \\
\hline & & 3 & 4 & 5 & 6 & 7 & 8 \\
\hline Means of age classes $\left(m_{i}\right)^{a}$ & & 0.500 & 0.400 & 0.300 & 0.200 & 0.100 & 0.000 \\
\hline Accuracy of selection $\left(r_{i}\right)$ & & 0.500 & 0.600 & 0.645 & 0.670 & 0.690 & 0.710 \\
\hline Proportions among classes & & 0.271 & 0.217 & 0.174 & 0.139 & 0.111 & 0.089 \\
\hline $\begin{array}{l}\text { No. of candidates } \\
\text { (total nos. } 2,500)\end{array}$ & & 677 & 541 & 433 & 347 & 277 & 222 \\
\hline \multicolumn{8}{|l|}{$\begin{array}{l}\text { Proportions of selected } \\
\text { parents }\end{array}$} \\
\hline Method $1^{b)}$ & $5.87^{\mathrm{cl}}$ & 0.271 & 0.217 & 0.174 & 0.139 & 0.111 & 0.089 \\
\hline Method II & 5.43 & 0.371 & 0.236 & 0.159 & 0.109 & 0.075 & 0.050 \\
\hline Method III & 5.51 & 0.332 & 0.249 & 0.173 & 0.117 & 0.078 & 0.052 \\
\hline Method IV & 5.60 & 0.293 & 0.260 & 0.186 & 0.125 & 0.082 & 0.054 \\
\hline \multicolumn{8}{|l|}{ Truncation points ${ }^{a}$} \\
\hline Method I & & 1.68 & 1.30 & 1.10 & 0.96 & 0.82 & 0.69 \\
\hline Method II & & 1.20 & 1.20 & 1.20 & 1.20 & 1.20 & 1.20 \\
\hline Method III & & 1.38 & 1.14 & 1.11 & 1.14 & 1.16 & 1.18 \\
\hline Method IV & & 1.57 & 1.08 & 1.03 & 1.07 & 1.12 & 1.14 \\
\hline \multicolumn{8}{|l|}{$\begin{array}{l}\text { Predicted genetic values on } \\
\text { truncation points }{ }^{a,} \text { d }\end{array}$} \\
\hline Method I & & 0.621 & 0.405 & 0.343 & 0.264 & 0.181 & 0.097 \\
\hline Method II & & 0.300 & 0.369 & 0.383 & 0.374 & 0.363 & 0.358 \\
\hline Method III & & 0.345 & 0.345 & 0.345 & 0.345 & 0.345 & 0.345 \\
\hline Method IV & & 0.392 & 0.324 & 0.310 & 0.315 & 0.322 & 0.327 \\
\hline \multicolumn{8}{|l|}{ Genetic superiorities $^{\text {al }}$} \\
\hline Method I & $0.665^{e 1}$ & 0.699 & 0.738 & 0.701 & 0.635 & 0.563 & 0.490 \\
\hline Method II & 0.676 & 0.607 & 0.710 & 0.732 & 0.722 & 0.706 & 0.695 \\
\hline Method III & 0.677 & 0.641 & 0.692 & 0.702 & 0.699 & 0.692 & 0.685 \\
\hline Method IV & 0.676 & 0.677 & 0.676 & 0.676 & 0.675 & 0.673 & 0.671 \\
\hline
\end{tabular}

a) in genetic s.d. units.

b) Methods refer to text.

c) generation intervals as average ages of selected parents.

d) as the deviation from the means of age class 3 .

e) average genetic superiorities as deviation from the means of age 3 . 
between consecutive age classes were assumed to be 0.1 genetic standard deviation $(75 \mathrm{~kg})$, based on the actual yearly improvement in dairy cattle population in Hokkaido ${ }^{14)}$, considering phenotypic standard deviation of 1,500 $\mathrm{kg}$ and heritability of 0.25 . The accuracies of selection were the rounded values based on an increase in a number of lactation records with older cows. The rate of selection was 500 cows from 2500 candidates. The assumed proportions of candidates among the age classes were relative proportions assuming their stayability to be 0.80 . Initial point of selection $\left(\mathrm{K}_{\mathrm{c}, 0}\right)$ was settled on the means of the youngest age class. The limited deviation of truncation points $(\mathrm{d}(\mathrm{K}),(\mathrm{h}(\mathrm{K}))$ and selection intensity $(e(K))$ at their convergence were settled to be $10^{-5}$ in equations (6), (6.1) and (14) respectively.

Under these conditions, the truncation point with a given selection intensity (Method IV) was obtained in less than 4 cycles. When the deviation of selected proportion converged to the limited threshold range, the number of iterations were 3 for Method Il and 9 for both Methods III and IV. When there were some differences in accuracy of selection among age classes, as in numerical example, the number of cycles required for the convergence increased.

The comparison of calculated age structures, truncation point and genetic selection differentials with 4 selection criteria, is presented in Table 1. When parents were selected according to Method II, the generation interval was the shortest of four methods ascrided to the higher proportion of selection from younger parents, followed by Method III and IV. However, the average genetic superiorities were highest for Method III followed by Method IV and II, though the differences among these three methods were very small. Age structures of parents (e.g. generation interval) and estimated genetic superiorities depend on the methods of selection applied. These quantities would also be affected by the number of age classes, genetic difference among age classes and the accuracy of selection. More work would be needed to determine an optimal method among those examined in this study with combinations of different genetic and population parameters.

Cows not selected as parents, in this model, were never used for breeding but were kept from one year to another for possible future use. In practice, breeder would be reluctant to pursue such a policy as already decribed by JAMES $^{12)}$ and HILL ${ }^{\text {9) }}$. The results achieved here have some similarity with COCHRAN ${ }^{3)}$ and HopkINS and JAMES ${ }^{10,11)}$. The distribution of actual dairy population of each age class would be skew due to earlier culling of low producers. In principle, the methods proposed in this paper would not be suitable for application to such a skewed population due to an implicit assumption of normal distribution. However, it may be of some interest to combine with HENDERSONS'S ${ }^{12)}$ BLUP method to predict breeding values.

\section{Acknowledgments}

The authors acknowledge Dr. N. Noguchi, Department of Agricultural Engineering, for his valuable suggestions on computational procedures. The results of this study were computed at the Hokkaido University Computing Center.

\section{References}

1) Bichard, M., A.H.R. Pearse, P.H. Swales and $\mathrm{K}$. Özkürük, Selection in a population with overlapping generations. Anim. Prod., 17 : 215-227. 1973.

2) Burrows, P.M., Expected selection differentials for directional selection. Biometrics, 28 : 1091-1100. 1972.

3) Cochran, W.G., Improvement by means of selection. in Proceedings of the second Berkely symposium on Math. Stat. and Prob. (Neyman, J.) 449-470. Univ. of California Press. Berkely. 1951.

4) Dennis, J.E. and R.B. Schnabel, Numerical methods for unconstrained optimization and nonlinear equations. 15-37. 


\title{
Shimizu and GHafFar
}

Prentice Hall. Englewood Cliffs. NJ. 1983.

5) Ducrocq, V. and R.L, QuaAs, Prediction of genetic response to truncation selection across generations. J. Dairy Sci., 71 : 25432553. 1988.

6) Fisher, R.A. and F. YAtes, Statistical Tables for Biological and Medical Research. 6th ed. Oliver and Boyd. Edinburugh. 1963.

7) Henderson, C.R. and R.L. QuaAs, Multiple traits evaluation using relatives' records. J. Anim. Sci., 43: 1188-1197. 1976.

8) Hit., W.G., Prediction and evaluation of response to selection with overlapping generations. Anim. Prod., 18: 117-139. 1974.

9) HILL, W.G., Selection with overlaping generations. in Proceedings of the International Conference on Quantitative Genetics. (Pollak, E., O. Kempthorne and T.B. Balley, Jr) 367-378. lowa State Univ. Press. Ames. 1977.
10) Hopkins. I.R, and J.W. JAMES, Some optimum selection strategies and age structures with overlapping generations. Anim. Prod., 25 : 111-132. 1977.

11) Hopkins, I.R. and J.W. JAMES, Genetic responses in the early years of selection programmes using genetic differences between generations. Anim. Prod., $28: 65-77$. 1979.

12) JAMES, J.W., Determination of optimal selection polices. J. Anim. Breed. Genet., 104 : 23-27. 1987.

13) Meuwissen, T.H.E., A deterministic model for the optimization of dairy cattle breeding based on BLUP breeding value estimates. Anim. Prod., 49: 193-202. 1989.

14) Tsuruta, S., M. Suzuk. and T. Mrrsumoto, Estimation of genetic and environmental trends from simultaneous genetíc evaluation of bulls and cows using Hokkaido Dairy Herd Milk Records. Jpn. J. Zootech. Sci., 61 : 1051-1056. 1990.

\section{世代重複集団における選抜切断点の演算法}

\author{
清水 弘 $\cdot$ Abdul GHAFFAR \\ 北海道大学農学部, 札幌市北区 060
}

\begin{abstract}
複数の年齢群を含む世代重複集団について，（1）各年齢群の選抜切断点が期待遗伝的能力值で等し い選抜，（2）各年龄群から選拔された種音の平均期待臬伝的能力值が等しくなる選抜，を実施する之 きの切断点を Newton 法で算出する方法を提示した．種雄牛母牛の選抜を数值例之して，侯補音上同 じ比率で選抜する年齢群内選抜と表型值ないしは選抜指標值で全年齢群に共通な切断点での選抜を含め, これら 4 方法の選抜の実施した時の選抜種畜の理論的な年齢棈成, 選抜切断点, 遺伝的選技差を示し， 本方法の適用性について考察した。
\end{abstract}

日畜会報, $63(11): 1109-1114,1992$ 